important structures in which it was used was Brunel's Thames tunnel. Aspdin's son, William (1816-64), played a considerable part in the development of the cement industry and erected works in Germany, where he died.

\section{British School of Archæology at Athens}

AT the annual meeting of the British School of Archæology at Athens, which was held at Burlington House, Piccadilly, London, W.1, on November 29, when the Crown Prince of Sweden was in the chair, Mr. J. D. S. Pendlebury gave an account of his recent excavation of the city of Karphi in Crete. This was one of the cities on the hills surrounding the plain of Lasithi; and its great interest lay in the fact that it contained an example of a large house, which probably dated from within two generations of the Trojan War, and thus afforded an excellent illustration of the house of Homeric times. The city was situated on an exposed spot with cliffs on three sides, that on the north having a sheer drop of 2,000 feet. It contained two cemeteries, a temple, and among other buildings, as already mentioned, a house, the largest of the period yet found. It is interesting to note that the roofing system of the whole town is that still in use among Cretan peasants. It would appear that bronze age civilization came to an end in Crete about 1100 B.C., when there was an invasion of people from outside, who introduced the Greek language, and settled at first near the sea. The old Minoans found sanctuary in the hills, where they continued to live on. Occupation at Karphi came to an end some two hundred years later, at about 900 B.c. Its evacuation, apparently, was peaceful, its inhabitants, no doubt, then considering it safe to live in a less exposed situation. In the course of the meeting, two announcements of no little importance were made. Prof. J. L. Myres, in moving the adoption of the annual report, stated that news had been received by the last mail of the discovery of an important Minoan tomb at Knossos, which was to be investigated at once; and Sir John Forsdyke announced that owing to the increase in the Government grant from $£ 500$ to $£ 1,000$ per annum, and the coming into operation of the Richard B. Seager bequest, the activities of the School in excavation would be considerably extended in the coming year.

\section{Woad Mills}

Amongst the many at one time flourishing industries connected with agriculture carried on in Great Britain was that of the cultivation and preparation of woad, and in a paper read by Mr. Rex Wailes before the Junior Institution of Engineers on November 25 is described its cultivation in gradually decreasing quantities down to 1932 , when the last crop in the world was gathered at Boston in Lincolnshire and prepared for market. Woad has been grown for centuries in Great Britain and prepared for market as a mordant or fixer for indigo dye. Its use in dyeing requires much skill, and its preparation is a lengthy process. The plant rapidly exhausts the soil in which it is grown, necessitating frequent removal of the woad mill and appurtenances to fresh sites. As in the case of many ancient industries, the woad mill evolved by village craftsmen seems peculiarly well fitted for its purpose. It ground the leaves into small pieces and after about an hour the mill was stopped and the pulped mass taken out and kneaded into balls about 6 in. in diameter ; these were stacked on trays in open tiers of gratings where they dried for some weeks, and were then removed to store-rooms preparatory to couching, the most difficult operation in the preparation of woad. The balls were first broken up by the rollers in the roller house and then taken to the couching barn near by and spread on the floor to a depth of about $3 \mathrm{ft}$., watered, and allowed to ferment. During this process, temperature was carefully controlled and not allowed to exceed $125^{\circ} \mathrm{F}$. The woad was turned daily at first and less frequently thereafter, the total time being 6-8 weeks. After couching, the woad was dried and rammed into barrels, its appearance then being like compressed peat or plug tobacco.

\section{Technical Training at Leeds}

The City of Leeds College of Technology enrolled in 1937-38 more than four thousand students, of whom all except 14 per cent attended evening classes only. In a report presented by the Principal on the occasion of a distribution of awards by Prof. Lancelot Hogben on November 29, an appeal was made to employers to promote a largely increased attendance at part-time day courses of technical training in principles. That serious practical difficulties stand in the way of large-scale releases of employees for this purpose was freely admitted, but few would be found to deny that there is a crying need for constructive effort to make good the gaps in vocational education resulting from the obsolescence of the apprenticeship system in industry. "In the great majority of trades at the present day the only 'qualification' for receiving the pay and status of a journeyman is the attainment of the age of 21." The Principal wants industrialists to co-operate with the College in devising schemes, separate for each trade, such as are already in operation in the engineering trade in the Midlands, for issuing some agreed form of 'apprenticeship certificate' giving full recognition to workshop training as well as to technical college work.

\section{Standard Time}

THE recent unveiling in Toronto, announced in The Times, of a bronze plaque of Sir Sandford Fleming, recalls that it was only sixty years ago that he proposed the system of standard time now universally used. The advent of railways and telegraphs to North America made the continued use of local time an inconvenient practice. The railways began to use their own time, which was seldom in accord with the local time of any place on the line. When more than one railway served a town, there were usually two or more railway times as well as the local time, and confusion was rife. Fleming, who was a Scot, became chief engineer of the Canadian Pacific Railway, and 
he realized that something must be done to end this state of confusion. In 1878, he proposed to the Canadian Institute in Toronto that the solution lay in dividing the globe into 24 time belts each of fifteen degrees of longitude, each belt to mark a difference of one hour in time. The Marquis of Lorne, at that time the Governor-General, submitted the proposal to the British Government, which, however, did not approve. The Tsar of Russia then initiated an international conference in Vienna in 1881 to discuss the matter. This led to a second conference in Washington in 1884 and the almost universal adoption of the proposal after the railways of Canada and the United States had already put standard time into use.

\section{Ramsay Memorial Fellowship}

THe following Ramsay Memorial fellowships for the year 1938-39 have recently been awarded: Dr. Vernon Hollis Booth, a British fellowship of $£ 300$, tenable for two years, at the University of Cambridge; Mr. Donald McNeil, a Glasgow fellowship of $£ 300$, tenable for two years at the University of Glasgow ; Dr. Alfred Epprecht, a Swiss fellowship of $£ 300$, tenable for one year, at the Imperial College of Science and Technology, London. The Trustees have renewed the following fellowships for a second year: Dr. A. E. Alexander (British fellow), at the University of Cambridge; Dr. E. de Salas (Spanish fellow), at University College, London; Dr. J. J. Hermans (Netherland fellow), at University College London; M. Jean Monvoisin (French fellow) at the Royal Institution, London; Mr. Hazime Oosaka (Japanese fellow), at University College, London; Dr. E. C. Stathis (Greek fellow), at the Imperial College of Science and Technology, London.

\section{Announcements}

Prof. H. Shapley, director of the Harvard College Observatory, Cambridge, Mass., has been elected a member in the Section of Astronomy, and Prince Louis-Victor de Broglie, of the Institut Poincaré, Paris, a member in the Section of Physics, of the Royal Swedish Academy of Sciences.

Prof. Emile Argand, professor of geology, mineralogy, petrography and palæontoology in the University of Neuchâtel, and Dr. E. A. Stensiö, director of the Department of Palæozoology in the Naturhistoriska Riksmuseum, Stockholm, have been elected foreign fellows of the Geological Society of London. Prof. H. von Eckermann, assistant professor of mineralogy and crystallography in the University of Stockholm, Prof. D. W. Johnson, professor of physiography in Columbia University, and Prof. A. A. Opik, professor of geology in the University of Esthonia, have been elected foreign correspondents.

Ar a meeting of the Royal Society of Edinburgh held on December 5, the president, Sir D'Arcy Thompson, showed and gave to the Society a copy of the billet of the corresponding meeting sixty years ago (December 16, 1878), when he had read a paper "On Ulodendron and Halonia" to the Society. This paper, communicated by Sir Wyville Thomson, was afterwards published by the Geological Society of Edinburgh, along with a plate drawn by another young man, known later on to all geologists as Benjamin Peach.

Honorary degrees have recently been conferred by the University of Paris on the following: Prof. Szent-Györgi, professor of medical chemistry in the University of Szeged faculty of medicine, Dr. S. P. L. Sörensen, director of the chemical section of the Carlsberg Laboratory, Copenhagen, and Dr. Karrer, director of the Institute of Chemistry, University of Zurich.

Prof. Jules Bordet, director of the Pasteur Institute of Brussels, was presented with the Grand Cross of the Legion of Honour at the opening meeting of the Congress of the Association of French-speaking Microbiologists.

The Sir Frederick Hobday Presentation Fund has

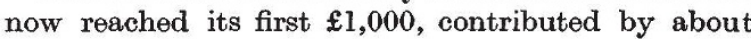
850 subscribers. The committee has decided to continue its work in order to obtain the amount necessary for the object which Sir Frederick Hobday had in view, namely, the endowment of a chair of comparative medicine. Subscriptions should be sent to the honorary secretary, Mr. E. T. Cox, 3 St. John's Avenue, S.W.15.

The Annual Conference of the Geographical Association will be held at the London School of Economics on January 3-6, 1939, under the presidency of Sir Thomas Holland. The subject of Sir Thomas's address will be "The Geography of Minerals". Further information can be obtained from the Clerk, Geographical Association, Municipal High School of Commerce, Princess Street, Manchester, 1.

THE annual meeting of the Institute of British Geographers will be held in the London School of Economics on January 5-6. Further information can be obtained from Mr. J. N. L. Baker, The University, Oxford.

THE twenty-seventh annual Conference of Educational Associations will be held at University College, London, W.C.I, on January 2-9, 1939, under the presidency of the Right Hon. Lord Macmillan. The subject of the presidential address will be "The Function of the University". A joint conference on "The University in a Changing World" will be held on January 5. Further information can be obtained from the Conference Secretary, Gordon House, 29 Gordon Square, W.C.1.

The Cambridge University Press is to publish shortly "Karl Pearson", a memoir consisting of two articles by his son. It surveys his life from his earliest days, giving extracts from letters to show the develop. ment of his philosophy, and details of his many activities. It is illustrated with many portraits, and there are appendixes summarizing his unpublished lectures and reports. 